\title{
Pendampingan Perencanaan Masterplan Gereja Santo Yoseph Paroki Medari, Sleman, Yogyakarta
}

\author{
${ }^{1}$ Andi Prasetiyo Wibowo, ${ }^{2}$ Djarot Purbadi \\ 1,2Prodi Arsitektur, Fakultas Teknik, Universitas Atma Jaya Yogyakarta \\ Email: ${ }^{1}$ andi.prasetiyo@uajy.ac.id, ${ }^{2}$ djarot.purbadi@uajy.ac.id
}

\section{Article Info}

Submitted: 29 October 2020 Revised: 29 December 2020 Accepted: 16 January 2021 Published: 21 April 2021

Keywords: masterplan, church, community service, design, spatial planning

Kata kunci: masterplan, gereja, pengabdian pada masyarakat, desain, tata ruang

\begin{abstract}
The Santo Yoseph Medari Church islocated in Sleman Regency, Yogyakarta. This church has regular worship activities (weekly eucharist) as well as several other activities. These activities include regular meetings, acolyte exercises, and informal meetings in an effort to strengthen the community. Some of these activities are scheduled, but many of them are incidental. These various activities are often concurrent, so there is a need for adequate pastoral care spaces, such as small group meeting rooms, large groups, and other spaces that are useful for supporting pastoral care. The existing rooms are not yet optimal, so they need to be rearranged. At the request of the parish, University of Atma Jaya Yogyakarta assigned a community service team to respond and assist these needs. This technical assistance team has assisted the church in designing the masterplan for the Santo Yoseph Medari Church. The masterplan that has been made adapts the existing conditions. It is expected to meet the needs of space, both as a support for religious activities at the Church of Santo Yoseph Medari and the activities of parishioners in general as well. Analysis of the site potential and functional requirements has been carried out during the design development process so that the resulting masterplan design is suitable for the needs of the community but still in accordance with the physical and cultural environment of the local community. The process of making the masterplan is divided into two stages (in broad outline), namely: data collection and initial analysis, followed by drafting and making design drawings consisting of area arrangement drawings and design proposals for supporting buildings.
\end{abstract}

Abstrak
Gereja Santo Yoseph Medari berada di daerah Kabupaten Sleman,
Yogyakarta. Gereja ini memiliki kegiatan ibadat rutin (ekaristi
mingguan) dan juga beberapa kegiatan lainnya. Kegiatan tersebut
antara lain rapat dewan, rapat bidang, rapat tim, pertemuan kelompok-
kelompok kategorial, latihan-latihan misdinar, dan perjumpaan
informal dalam upayamempereratpaguyuban umat. Kegiatan-kegiatan


tersebut ada yang terjadwal, namun banyak pula yang insidental. Aneka kegiatan ini seringkali bersamaan sehingga perlu adanya ruang-ruang pelayanan pastoral yang memadahi, seperti ruang rapat kelompok kecil, kelompok besar, dan ruang lainnya yang berguna bagi penunjang pelayanan pastoral. Ruang-ruang yang ada saat ini dirasa belum optimal sehingga perlu ditata ulang. Atas permintaan pihak paroki, Universitas Atma Jaya Yogyakarta menugaskan tim pengabdian masyarakat untuk merespon dan membantu kebutuhan tersebut. Tim pendampingan teknis ini telah mendampingi pihak gereja dalam upaya mendesain masterplan Gereja Santo Yoseph Medari. Masterplan yang telah dibuat menyesuaikan dengan kondisi eksisting tapak yang ada dan diharapkan dapat memenuhi kebutuhan ruang, baik sebagai pendukung kegiatan gerejawi di Gereja Santo Yoseph Medari maupun sebagai pendukung kegiatan umat paroki secara umum. Analisis terhadap potensi tapak dan kebutuhan fungsi telah dilakukan selama proses pengembangan desain agar desain masterplan yang dihasilkan sesuai untuk kebutuhan umat namun tetap sesuai dengan lingkungan fisik dan budaya masyarakat setempat. Proses pembuatan masterplan dibagi menjadi 2 tahap (secara garis besar), yaitu: pengumpulan data dan analisa awal, yang dilanjutkan dengan pembuatan konsep dan pembuatan gambar desain yang terdiri dari gambar penataan kawasan danusulan desain bangunan penunjang.

\section{PENDAHULUAN}

Luas wilayah Paroki Medari adalah 121 $\mathrm{Km}^{2}$. Jarak terjauh dari utara-selatan: $23 \mathrm{Km}$ sedangkan jarak terjauh dari barat-timur: $11 \mathrm{Km}$. Kondisi wilayah sebagian besar berupa dataran rata dan sisanya berupa perbukitan yang hampir semua lahannya sudah dimanfaatkan untuk mata pencaharian (pertanian-perkebunan) oleh masyarakat sekitar (P. H. 80 T. P. S. Y. Medari, 2010). Letak Paroki ini berada di antara paroki lain, yakni di sebelah Barat adalah Paroki St. Theresia Salam, di Utara adalah Paroki St. Yohanes Rasul Somohitan, di Timur adalah Paroki St. Aloysius Gonzaga Mlati, dan di Selatan adalah Paroki St. Petrus Paulus Klepu. Secara administratif pemerintahan, Paroki Medari melayani 3 Kecamatan, yaitu: Sleman, Tempel, dan Seyegan (P. I. P. Medari, 2005).

Berdasarkan jumlah umat dan letakgeografi, sejak tahun 2018 Paroki Medari terbagi ke dalam 6 wilayah yang terdiri dari 30 lingkungan. Empat wilayah dengan total 22 lingkungan berada di Pusat Paroki Medari sedangkan dua wilayah dengan 8 lingkungan berada di Stasi Seyegan. Menurut Pendataan Umat tahun 2011 warga paroki yang tercatat/terdata ada
1.054 keluarga dengan jumlah jiwa ada 3.318 orang. Mereka tersebar di 27 lingkungan dalam 6 wilayah dengan 1 paroki induk dan 1 stasi (sebelum lingkungan dimekarkan menjadi 30 Lingkungan). Berdasarkan jumlah umat Katolik yang tinggal dalam paroki ada 3.114 orang. Jika dikelompokkan, umat yang tinggal di pusat paroki ada 808 Kepala Keluarga (KK), sedangkan yang tinggal di stasi ada $346 \mathrm{KK}$. Menurut perkiraan, jumlah umat Paroki Medari 5 tahun terakhir situasinya masih sama dengan sekarang ini, bahkan akan tetap sama 15-20 tahun ke depan. Tidak ada penambahan umat secara signifikan karena dalam Rencana Tata Ruang Wilayah (RTRW) Kabupaten Sleman 2011-2031 tidak ada rencana pengembangan kawasan perumahan, perkotaan, atau perindustrian di wilayah ini.

Gereja ini memiliki kegiatan ibadat rutin (ekaristi mingguan) dan juga beberapa kegiatan lainnya. Kegiatan tersebut antara lain rapat dewan, rapat bidang, rapat tim, pertemuan kelompok-kelompok kategorial, latihan-latihan misdinar, dan perjumpaan informal dalam upaya mempererat paguyuban umat. Kegiatan-kegiatan tersebut ada yang terjadwal, namun banyak 
pula yang insidental. Permasalahan yang sering dihadapi, yaitu kapasitas gereja yang sudah tidak bisa menampung umat, khususya saat hari besar gerejawi/perayaan, di mana panitia harus menyewa tenda dan kursi untuk melayani umat (Rm. Antonius Dadang Hermawan, 2018). Selain kegiatan ekaristi mingguan, umat berkegiatan juga di paroki. Permasalahan lain muncul yaitu aneka kegiatan ini seringkali bersamaan waktunya sehingga perlu adanya ruang-ruang pelayanan pastoral yang memadahi, seperti ruang rapat kelompok kecil, kelompok besar, dan ruang lainnya yang berguna bagi penunjang pelayanan pastoral. Ruang- ruang yang belum optimal perlu ditata ulang. Pelimpahan aset bangunan bekas SMA Agustinus juga perlu ditata ulang dan disatukan dengan seluruh kebutuhan pelayanan pastoral Paroki Medari.

Paroki Medari ingin memberikan pelayanan pastoral yang lengkap dan hadir sebagai gereja di tengah masyarakat. Dari data awal diketahui problema fungsi fasilitas gereja belum berdayaguna dan efektif mendukung pencapaian pelayanan pastoral yang diharapkan. Dengan problema spesifik yaitu fasilitas dan integritas fasilitas gereja yang dirasa masih kurang dalam upaya mendukung fungsi gereja katolik yang bersinergi dan menjadi berkat bagi masyarakat sekitar. Perlu adanya perencanaan kawasan yang dapat memenuhi harapanharapan tersebut. Dengan adanya perencanaan dan tata kawasan yang baik, Paroki Medari akan dapat memberi pelayanan pastoral yang berdaya guna, komunikatif, efektif, efisien dengan tetap menghadirkan wajah gereja di tengah masyarakat sekitar. Arah pastoral yang ditempuh tentu berdasarkan Rencana Induk Keuskupan Agung Semarang (RIKAS) 20162035, yakni "Terwujudnya Peradaban Kasih dalam Masyarakat Indonesia yang Sejahtera, Bermartabat dan Beriman".

\section{METODE}

Pada tahun 2005, tim dari Universitas Atma Jaya Yogyakarta pernah membantu membuatkan masterplan untuk gereja Medari. Hanya saja, masterplan tersebut sudah tidak relevan karena dalam perkembangan Paroki Medari saat ini, di mana adanya hibah aset eks SMA Agustinus pada tahun 2007. Selain tanah, aset hibah juga berupa ruang-ruang kelas yang selama ini dimanfaatkan untuk pendampingan penerimaan sakramen inisiasi (baptis, komuni pertama, dan penguatan) dan Pendidikan Anak Usia Dini (PAUD). Ruangruang bekas SMA Agustinus masih dapat dipakai, tetapi tidak terintegrasi dengan ruang-ruang lain yang dimiliki oleh paroki.

Proses pembuatan masterplan secara garis besar terdiri dari pengumpulan data dan analisa awal, yang dilanjutkan dengan pembuatan konsep dan pembuatan gambar desain yang terdiri dari gambar penataan kawasan dan usulan desain bangunan penunjang. Secara garis besar alur kegiatan pengabdian pada masyarakat ini dapat dilihat pada gambar 1 . Kegiatan pendampingan pengabdian ini berjalan selama kurang lebih 1,5 tahun dalam rentang waktu April 2018 - Oktober 2019.

Pemetaan permasalahan berangkat dari bawah (bottom up) dengan menggali permasalahan yang sangat mendasar dari warga diyakini menjadi metode yang paling tepat dalam menentukan arah kebijakan pengembangan sebuah kawasan (Sastrawan, 2019), (Sastrawan, Darmawan, \& Widanan, 2018). Keterlibatan sejak tahap perencanaan pembangunan diharapkan mampu menciptakan rasa memiliki dan tanggung
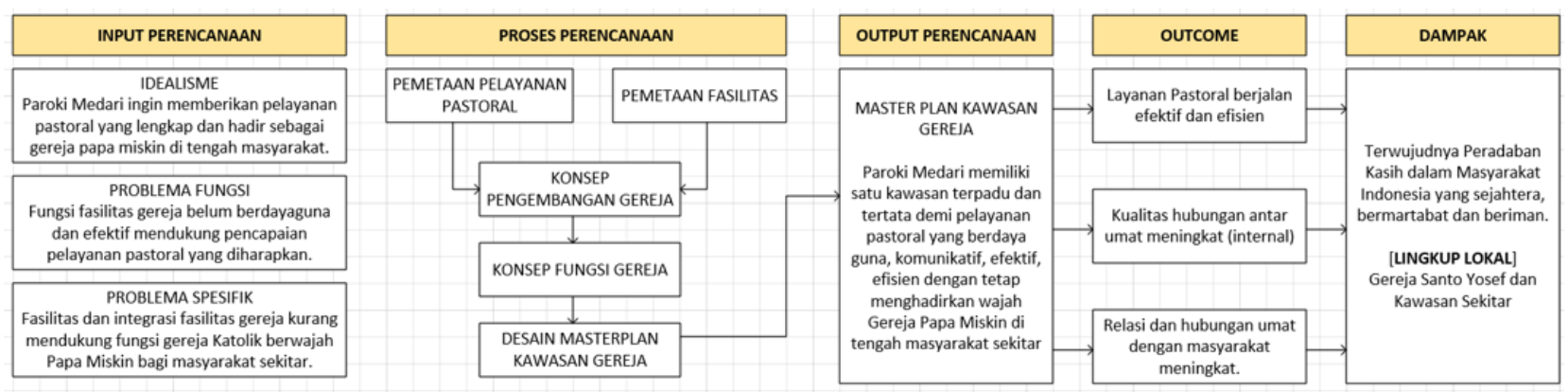

Gambar 1. Tahapan Penyelesaian Masalah dan Proses Desain 
jawab bersama (Indrastanti, Bawono, Nursiam, Sari, \& Mukharomah, 2017). Oleh sebab itu, umat/warga gereja dilibatkan sejak awal dengan adanya pengisian kuesioner yang dilakukan oleh semua pihak yang terlibat. Dengan adanya hasil kuesioner ini diharapkan mampu mempermudah proses identifikasi dan analisis masalah serta sebagai sarana untuk menjaring usulan/ masukan dari warga/umat. Partisipatif warga juga memungkinkan adanya pemetaan potensi yang bisa mendukung atau setidaknya menjadi pertimbangan ketika akan membuat sebuah kebijakan yang berdampak pada banyak orang/ msyarakat (Srirejeki, Faturahman, Warsidi, Ulfah, \& Herwiyanti, 2020).

\section{HASIL DAN PEMBAHASAN}

Proses pembuatan masterplan secara garis besar terdiri dari pengumpulan data dan analisa awal, yang dilanjutkan dengan pembuatan konsep dan pembuatan gambar desain yang terdiri dari gambar penataan kawasan dan usulan desain bangunan penunjang. Secara garis besar alur kegiatan pengabdian pada masyarakat ini dapat dilihat pada gambar 1 .

Perencaanaan masterplan ini mengacu pada konsep arsitektur modern yang memperhatikan aspekfungsional, aspek kontekstual, aspekkinerja, aspek teknik/struktur, aspek arsitektural (M Nur dan Priyoga, 2015a) (M. Nur dan Priyoga, 2015b). Selain itu akulturasi dengan budaya setempat juga ditargetkan akan mampu memberikan nilai tambah pada desain dan terciptanya proses inkulturasi (Mayang Sari, 2007).

Proses perencanaan masterplan dibahas dengan mengelompokkan menjadi menjadi beberapa bagian yang menggambarkan proses analisis terhadap permasalahan dan alternatif solusinya. Adapun bagian-bagian tersebut terdiri dari zonasi, gubahan massa, sirkulasi, tata air dalam lahan, penataan vegetasi, tata ruang, penambahan dan relokasi ruang, dan penataan parkir.

\section{Zonasi}

Kondisi zonasi mula-mula pada Gereja Medari dinilai masih kurang tertata karena tidak memperhatikan zonasi berdasarkan sifat kegiatan. Zona bangunan pastoran yang seharusnya memiliki sifat privat ternyata terletak di bagian depan. Zona bangunan pelayanan pastoran seharusnya berfungsi pula sebagai area transisi antara gedung Gereja (sakral) dan publik serta antara pastoran (privat) dan publik tidak dapat diwujudkan. Zona bangunan sekolah terletak di belakang padahal seharusnya memiliki sifat publik dan mudah diakses.

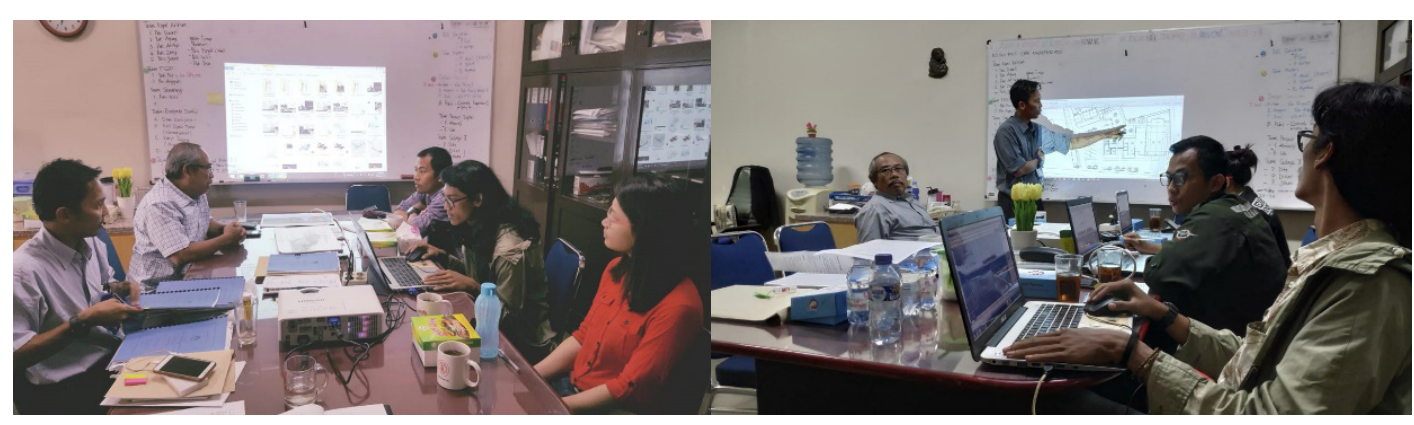

Gambar 2. Rapat Koordinasi tim

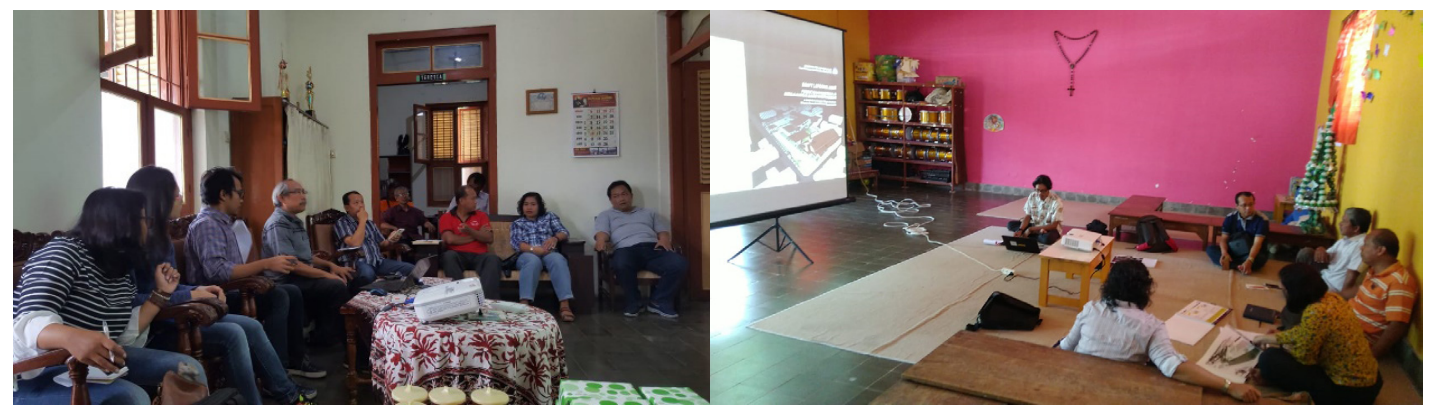

Gambar 3. Presentasi/Diskusi dengan Pihak Gereja Medari 


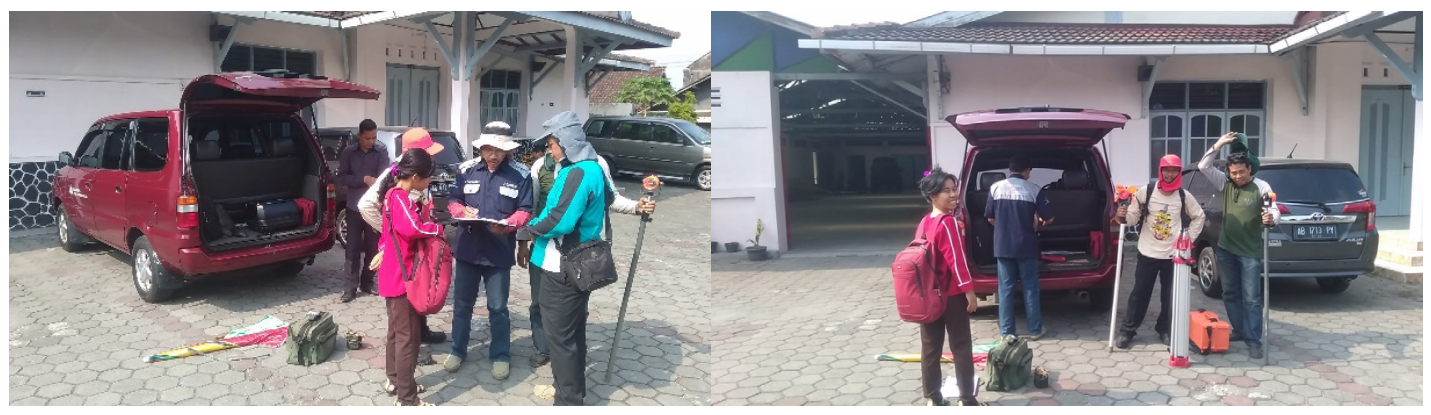

Gambar 4. Persiapan Kegiatan Pengukuran/Pemetaan Lahan Eksisting

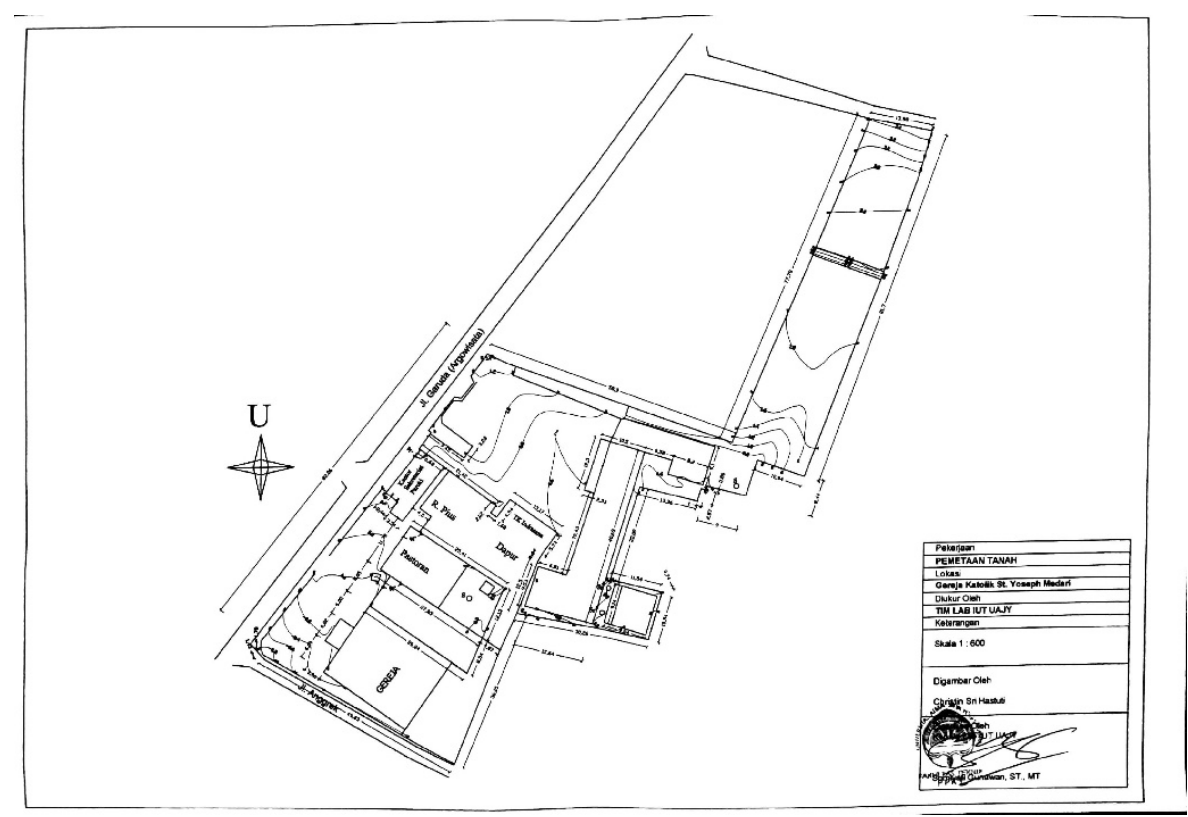

Gambar 5. Hasil Pengukuran Lahan Eksisting sebagai Acuan Perencanaan, Lengkap dengan Keterangan Elevasi/Kontur Tanah
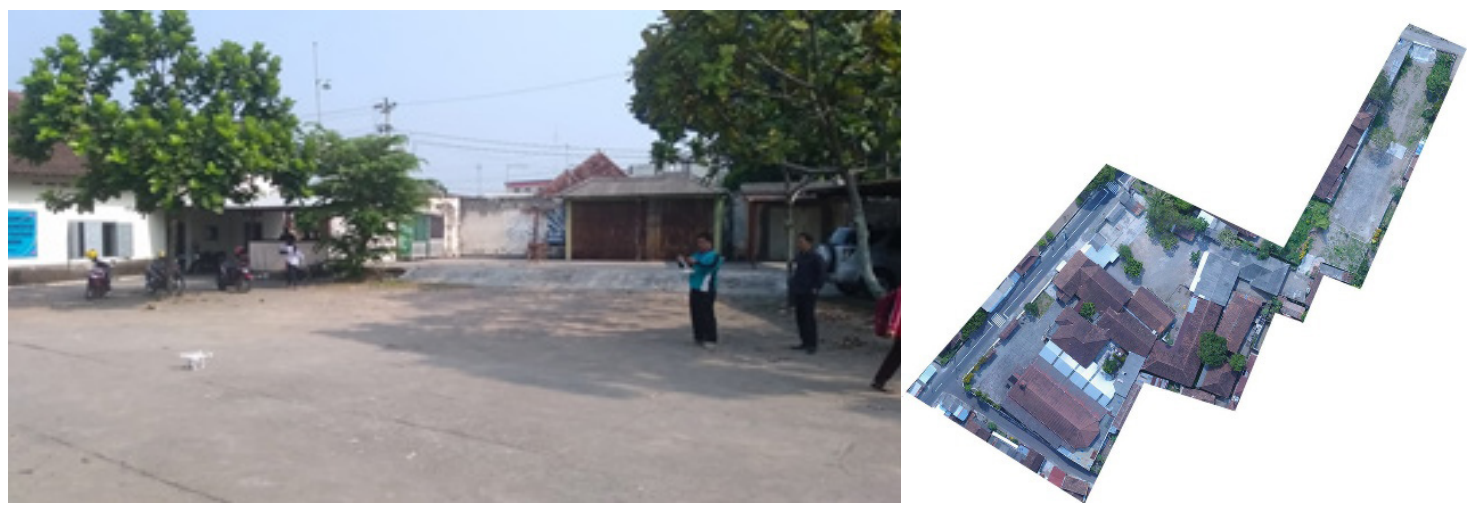

Gambar 6. Proses Pemotretan Citra/Foto dari Udara Dengan dengan Menggunakan Drone (kiri). Hasil citra/foto udara (kanan)

Kondisi eksisting Gereja Santo Yoseph Medari memiliki tata zonasi yang kurang teratur dilihat dari aspek kegiatan dan suasana ruang (sakral-profan). Zona sakral sebagai zona utama seharusnya menjadi acuan bagi tata zonasi yang lain (zona pendukung). Untuk memperkuat karakkter dari zona sakral ini, elemen-elemen dekoratif dan yang memperlihatkkan simbolsimbol gereja perlu menjadi perhatian dalam proses pengembangan bangunan gereja dan kawasan (Chrisylla, 2016). Zona pendukung direncanakan untuk mampu menjadi zona 
yang melayani secara efektif dan transisi antara zona sakral dan zona sekolah. Penataan zonasi direncanakan untuk bisa memenuhi prinsip kelancaran kegiatan, kemudahan akses, dan mendukung relasi antar kelompok ruang di dalam zona dan dengan di luar zona.

Dari hasil analisis, penataan zona gereja akan dibedakan menjadi empat zona utama dan satu zona tambahan yang disebut sebagai zona devosi yang menjadi bagian dari zona transisi. Area gedung gereja yang memiliki sifat sakral akan tetap berada sesuai kondisi awal. Zona pelayanan karya pastoral sebagai area transisi antara gedung gereja (sakral), pastoran (privat), dan zona publik. Area belakang difungsikan sebagai zona pastoran karena membutuhkan privasi dan suasana hening bagi pastor untuk berdoa. Untuk memberikan adanya ruang transisi, maka pada bagian tengah site akan diciptakan area hijau yang sekaligus berfungsi sebagai area devosi.

\section{Penataan Massa}

Penataan massa eksisting pada Gereja Santo Yoseph Medari dibagi menjadi 6 zona berdasarkan fungsi yaitu, gedung gereja, pastoran, pelayanan karya pastoral, sekolah, parkir, dan area servis. Massa dari gedung utama Gereja Santo Yoseph Medari sudah tepat tetapi massa bangunan yang lain kurang tertata karena penambahan massa atau gedung baru dilakukan atas dasar kebutuhan mendesak. Penataan massa juga akan memperhatikan elemenelemen arsitekturalnya, apakah cukup dilakukan pemindahan/perbaikan atau penggantian/ pembangunan dengan material yang baru, mengingat material penyusun elemen bangunan tersebut berbeda-beda karakternya (Hadinata \& Yusran, 2019).

Massa bangunan eksisting yang dirubah pada area Gereja Medari adalah massa bangunan pada zona karya pastoral, sekolah

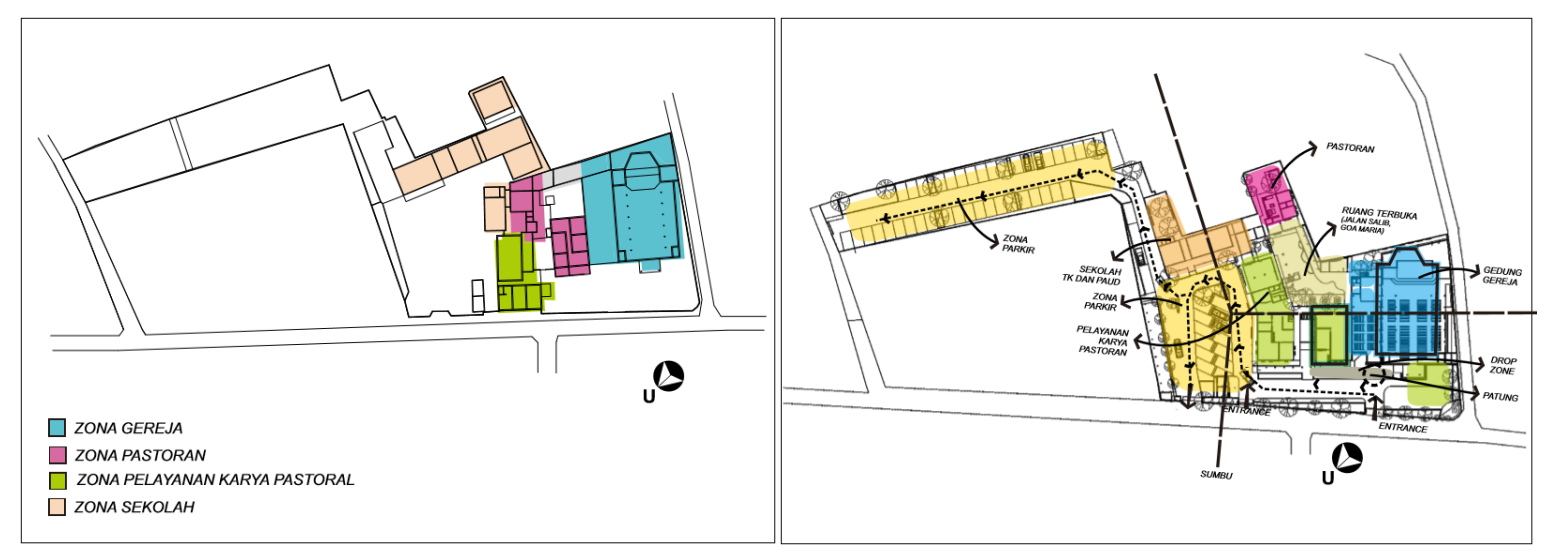

Gambar 7. Analisis Penataan Zonasi Kawasan. Eksisting (kiri) dan Usulan (kanan)

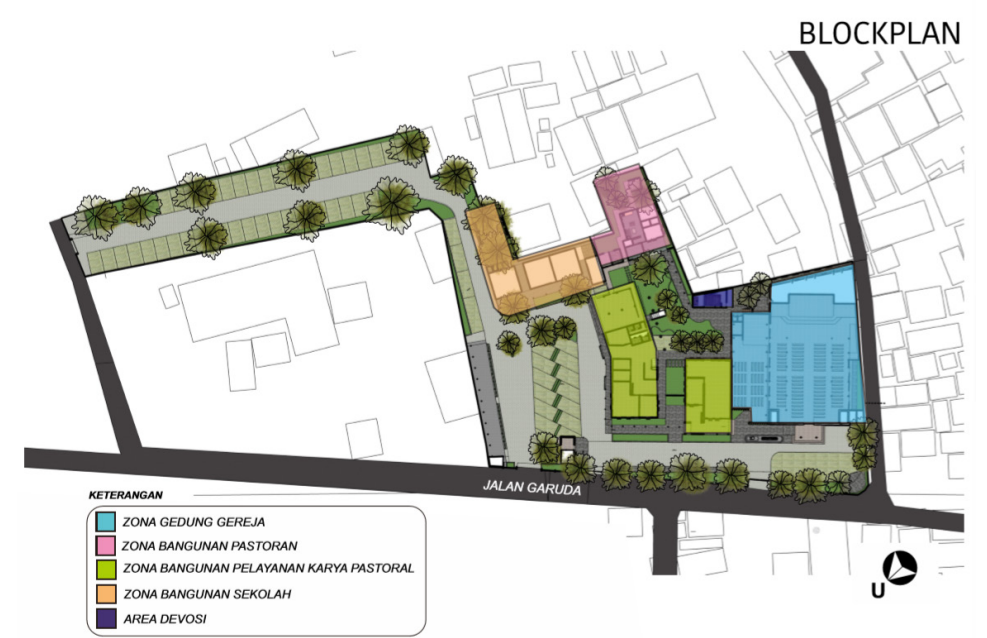

Gambar 8. Zonasi Kawasan yang Diusulkan 


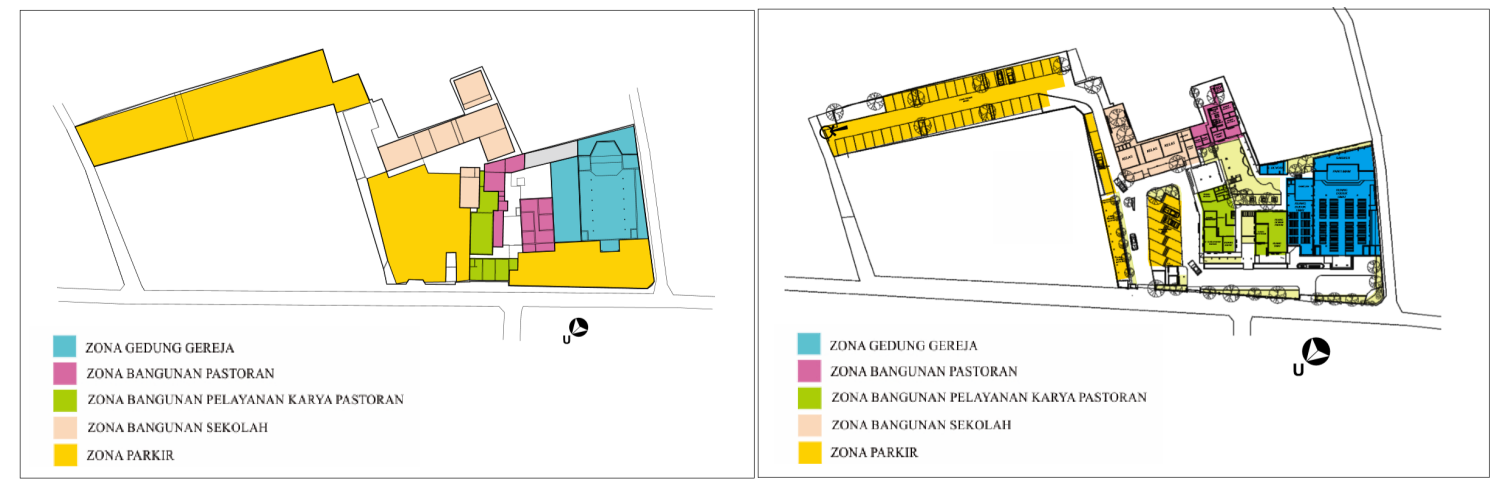

Gambar 9. Penataan Massa Bangunan. Eksisting (Kiri) dan Usulan (Kanan)

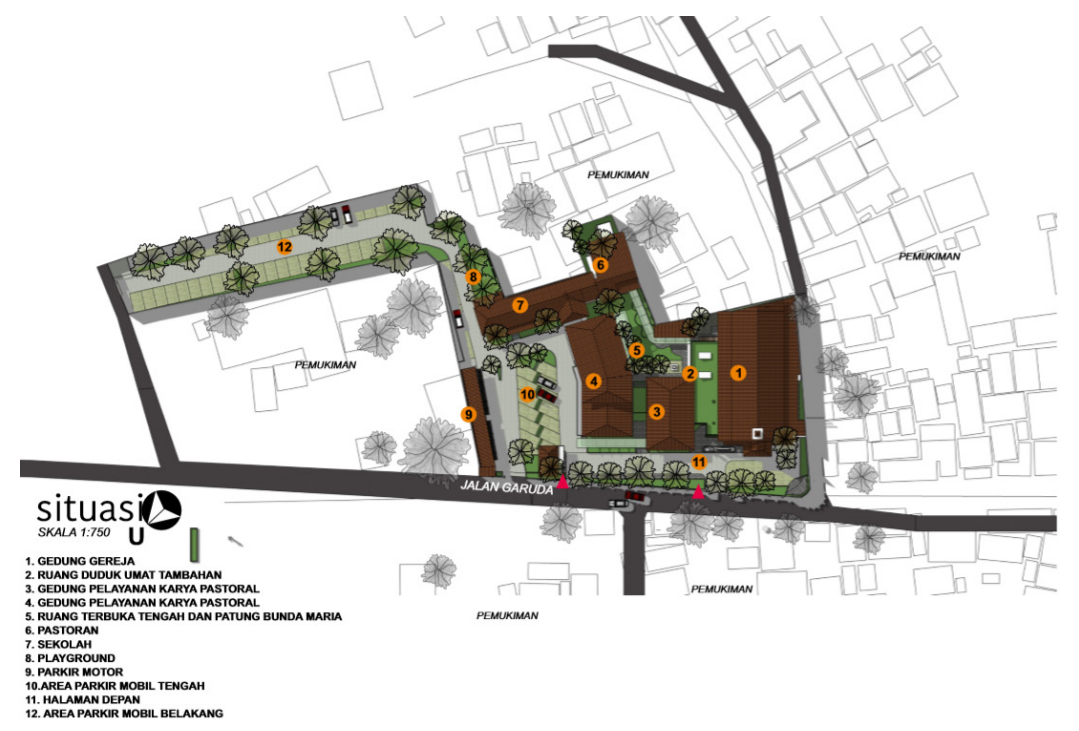

Gambar 10. Gambar Situasi

dan sebagian massa bangunan pada gedung gereja. Massa bangunan pada zona karya pastoral diubah menjadi lebih sederhana dan menyesuaikan grid dari massa bangunan gedung gereja. Massa bangunan sekolah yang terletak di paling ujung belakang site dialih fungsikan dan ditransformasi menjadi area pastoran. Area yang difungsikan untuk sirkulasi kendaraan dan sirkulasi pejalan kaki, khususnya difungsikan untuk drop zone. Agar massa bangunan baru tidak menonjol maka pada massa bangunan karya pastoral bagian depan dilakukan pengurangan/substractive pada bagian atas. Sehingga dari tampak depan bangunan terlihat seperti hanya memiliki satu lantai.

Penataan massa bangunan mempertimbangkan fungsi keseluruhan secara sistemik, termasuk memperhitungkan zonasi berdasarkan fungsi sakral dan profan. Massa gereja menjadi titik orientasi aktivitas sakral (religius), sedangkan massa bangunan lain mendukungnya, dengan titik orientasi pada fasilitas pelayanan pastoral. Massa untuk tempat tinggal pastor paroki diletakkan secara khusus agar aksesibel dari massa gedung gereja dan massa gedung pelayanan pastoral; dengan tetap menjaga privasi untuk kehidupan pribadi pastor. Penempatan bangunan pelayanan pastoral harus mudah diakses oleh umat (termasuk kaum difabel).

\section{Sirkulasi}

Ketidakteraturan gubahan massa berpengaruh pada pola sirkulasi kendaraan dan manusia. Ketidakteraturan pada sirkulasi manusia terihat dari area parkir menuju gereja dan sebaliknya yang harus melewati lorong cukup sempit dan hanya dapat dilalui maksimal dua orang berjajar. Padahal saat misa mingguan dan hari besar jumlah umat sangat banyak dan membutuhkan area sirkulasi yang lebih luas. 
Agar memudahkan dan mengoptimalkan sirkulasi kendaraan maka area halaman depan hanya difungsikan sebagai area pejalan kaki dan area drop off sehingga kendaraan khususnya bermotor roda empat diarahkan menuju ke area parkir. Terdapat dua akses sirkulasi umat khususnya pengguna kendaraan sehingga saat misa mingguan dan hari besar saat jumlah umat yang datang lebih banyak bisa lebih nyaman saat berjalan dari area parkir menuju gedung gereja.

Massa bangunan eksisting yang tidak teratur (penambahan massa dan pengaturannya berdasarkan kebutuhan mendesak) menyebabkan terjadinya ruang-ruang terbuang (lost spaces) dan sistem sirkulasi yang berpola tidak teratur. Penataan massa (desain massa, orientasi massa, relasi massa dengan massa lain) dipertimbangkan agar menghilangkan ruangruang terbuang (lostspaces), menciptakan sistem sirkulasi yang jelas, memisahkandan memberi fasilitas bagi sirkulasi manusia, dan kendaraan yang mendukung tercapainya kelancaran dan kenyamanan bergerak.

\section{Tata Air Dalam Lahan}

Air hujan menjadi masalah yang selalu terjadi karena terjadi genangan di dalam lahan gereja. Air hujan cenderung menggenang dan menimbulkan kesulitan akses sirkulasi dan ketidakberfungsian sebagian lahan gereja pada saat terjadi genangan. Air hujan tidak cepat meresap dan mengalir ke luar lahan atau meresap ke dalam tanah karena sistem tata air kurang terencana dengan memadai.

Karya arsitektur akan dianggap berhasil ketika tidak hanya mampu menyelesaikan sebuah permasalahan yang ada, namun juga ketika mampu memaksimaalkan potensi iklim
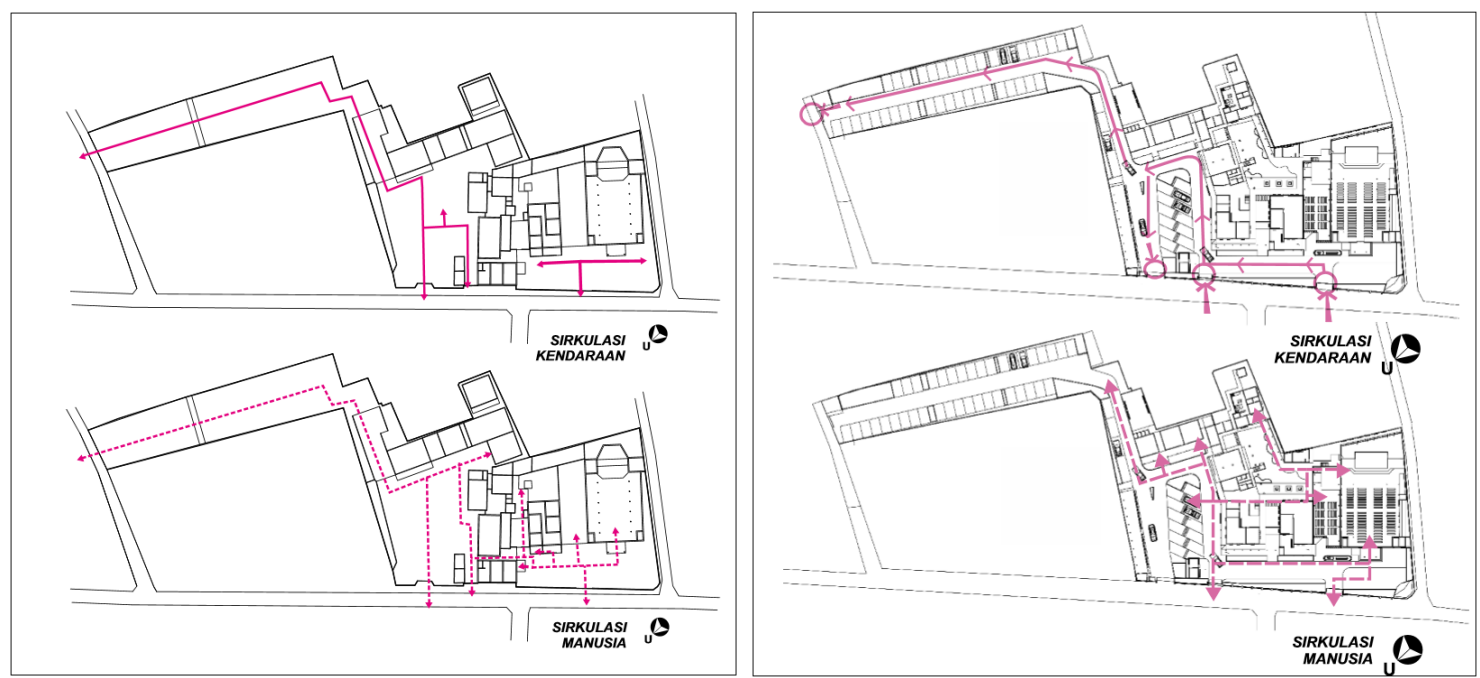

Gambar 11. Penataan Sirkulasi. Eksisting (Kiri) dan Usulan (Kanan)

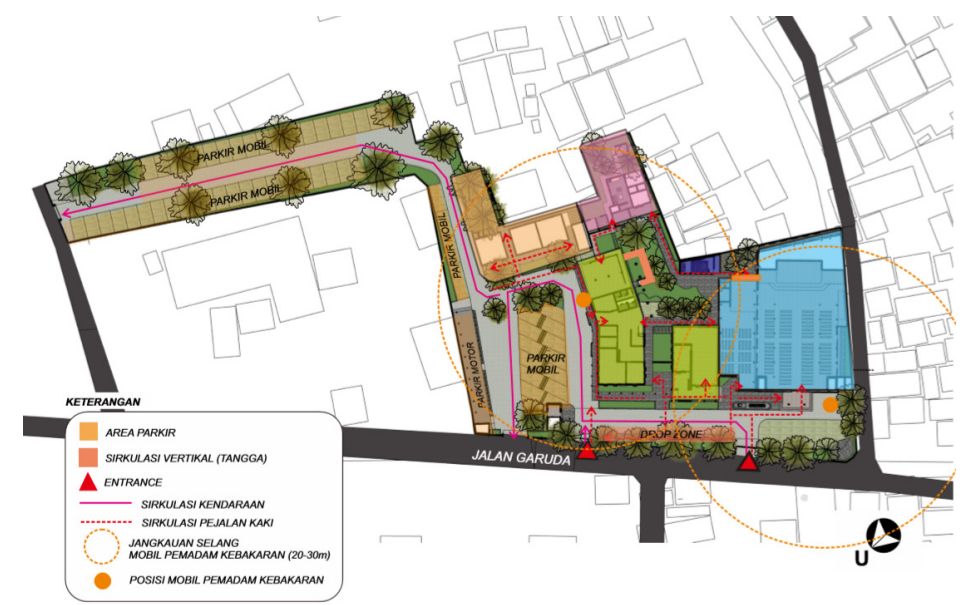

Gambar 12. Penataan Sirkulasi juga Sudah Memikirkan Akses untuk Mobil Pemadam Kebakaran 
(Sukawi, 2008). Kondisi curah hujan yang tinggi pada daerah tropis seharusnya bisa dijadikan potensi ketersediaan sumber air bersih. Artinya, lahan harus disiapkan mampu menampung air hujan dengan cara meresapkannya ke dalam tanah. Perlu disiapkan sistem tata air yang mampu menampung dan meresapkan air hujan sambil menjaga agar tidak terjadi gangguan ketika suasana hujan. Dengan demikian, tata air hujan di dalam lahan perlu diatur dan dilengkapi fasilitas penampung atau peresap air hujan secara memadai.

Penambahan fasilitas untuk meresapkan air hujan di dalam lahan yang tersedia dilakukan dengan cara menambah sumur-sumur resapan air hujan yang diperhitungkan sesuai kebutuhan. Jumlah dan letak sumur-sumur resapan direncanakan dengan baik sehingga nantinya akan dapat bersinergi dengan gubahan massa bangunan, pola sirkulasi orang dan kendaraan, dan tatanan ruang yang terbentuk.

\section{Penataan Vegetasi}

Gereja Santo Yoseph Medari memiliki lahan terbuka yang tersebar di seluruh area site. Area ruang terbuka utama nantinya akan diletakkan di tengah site berupa ruang terbuka hijau yang diharapkan mampu memberi pasokan udara bersih pada area Gereja Santo Yoseph Medari. Ruang terbuka hijau ini juga dapat difungsikan sebagai area pelaksanaan kegiatan umat dan area doa.

Area gereja seluruhnya diusahakan memiliki tata hijau lahan yang terencana agar lahan gereja menjadi relatif dingin sehingga diharapkan dapat mengurangi efek urban heat island. Tata hijau berupa pepohonan ditata sesuai kebutuhan, dikaitkan dengan pemanfaatan oleh massa bangunan dan jalur sirkulasi (orang dan kendaraan). Penambahan dan penataan pepohonan dilakukan dengan prinsip menghasilkan bayangan yang mendukung ruang kegiatan dan upaya menghasilkan oksigen
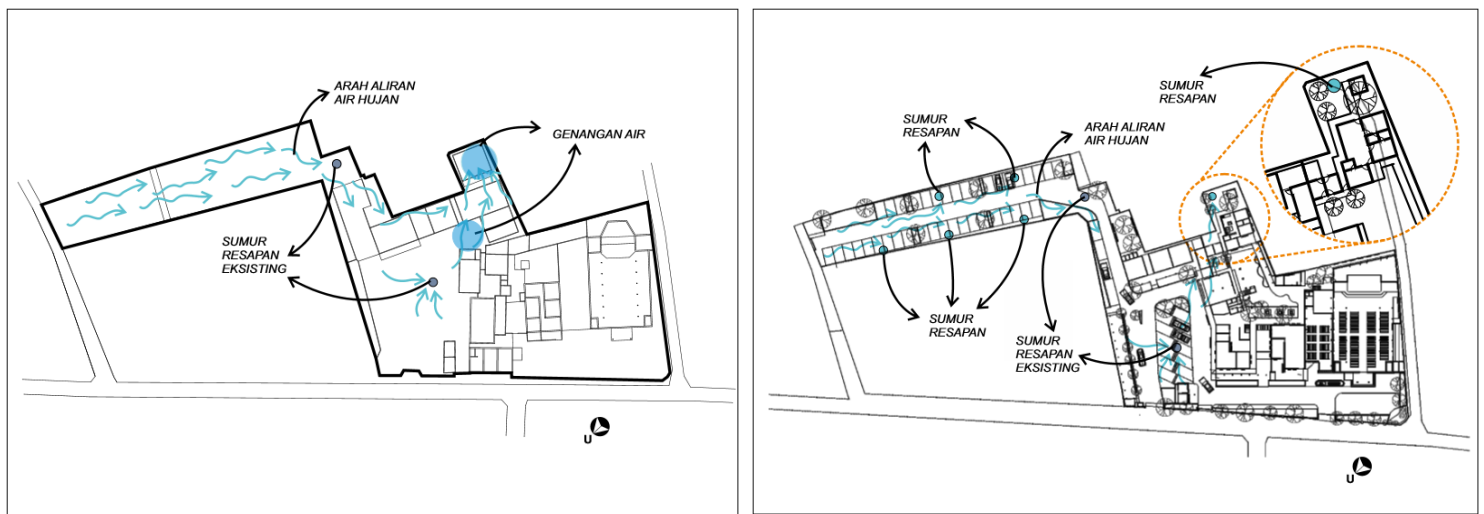

Gambar 13. Antisipasi Limpasan Air Hujan pada Kawasan. Eksisting (Kiri) dan Usulan (Kanan)

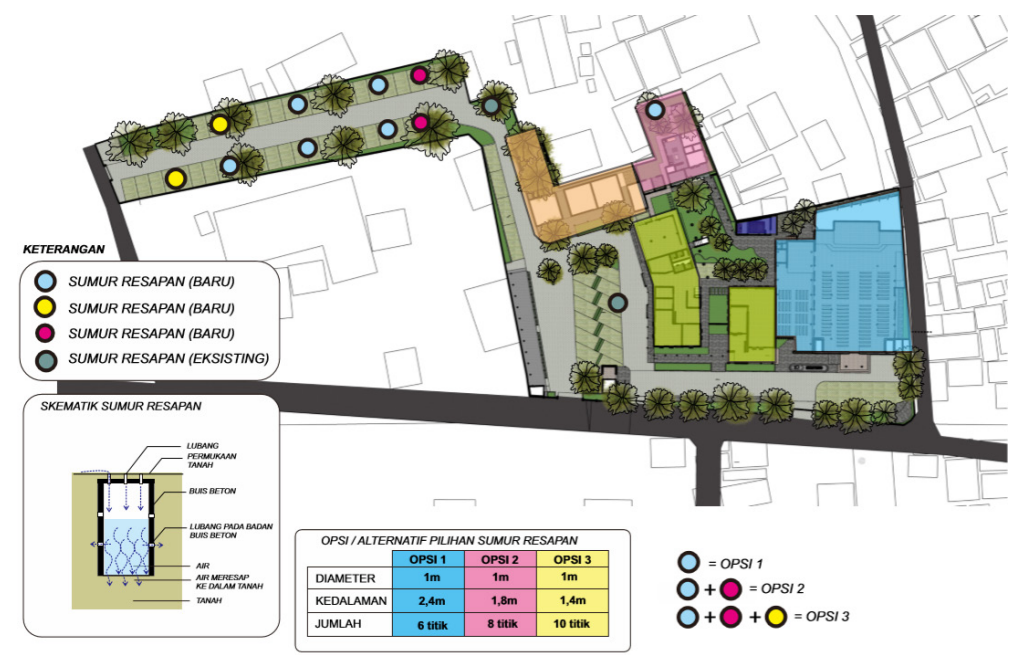

Gambar 14. Usulan Penempatan Sumur Resapan untuk Antisipasi Terjadinya Genangan Akibat Limpasan Air Hujan 
Wibowo dan Purbadi - Pendampingan Perencanaan Masterplan Gereja ...

di siang hari. Dengan demikian pepohonan bermanfaat bagi pembentukan ruang-ruang fungsional sekaligus upaya menghasilkan udara yang bersih, sehat dan sejuk dan dapat menjadi elemen estetika (Sumoprayogo \& Arifin, 2018).
Pemanfaatan ruang di atas bangunan sebagai green roof bisa menjadi alternatif penyediaan ruang terbuka hijau dalam upaya mendukung konsep eco-friendly building (Wibowo, 2014).
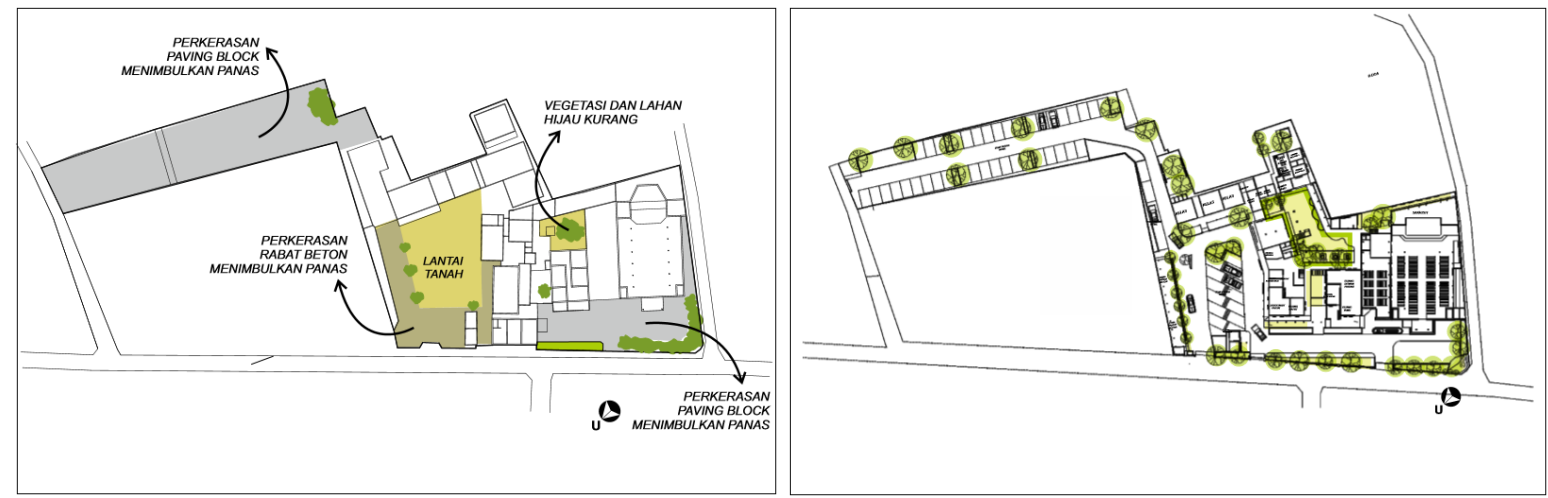

Gambar 15. Sistem Penataan Vegetasi Kawasan. Eksisting (Kiri) dan Usulan (Kanan)

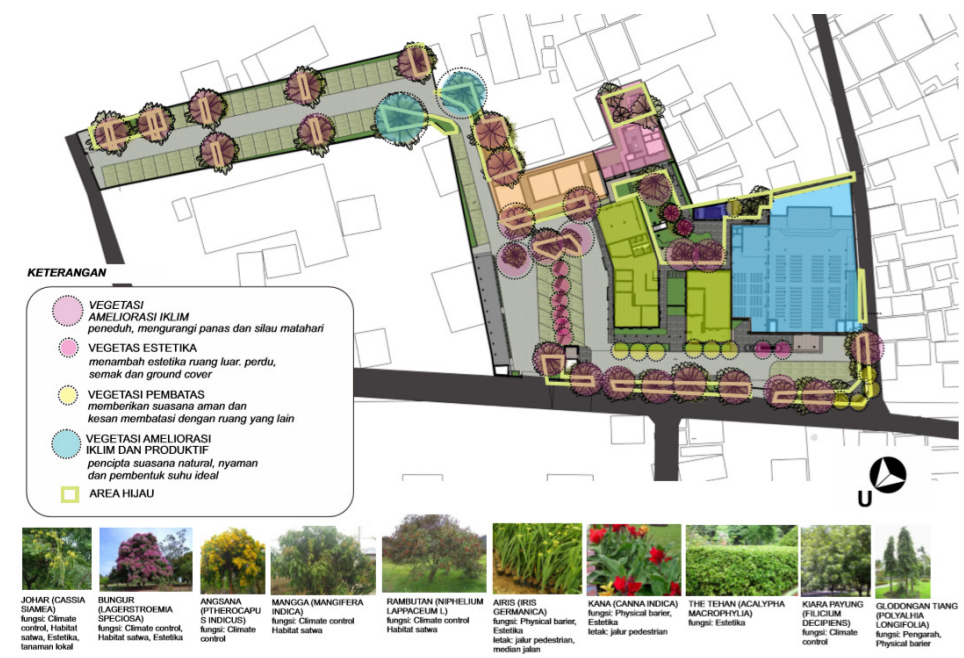

Gambar 16. Sistem Penataan Vegetasi Kawasan dan Usulan Jenis Tanaman yang Menyesuaikan Karakter Ruang dan Fungsi

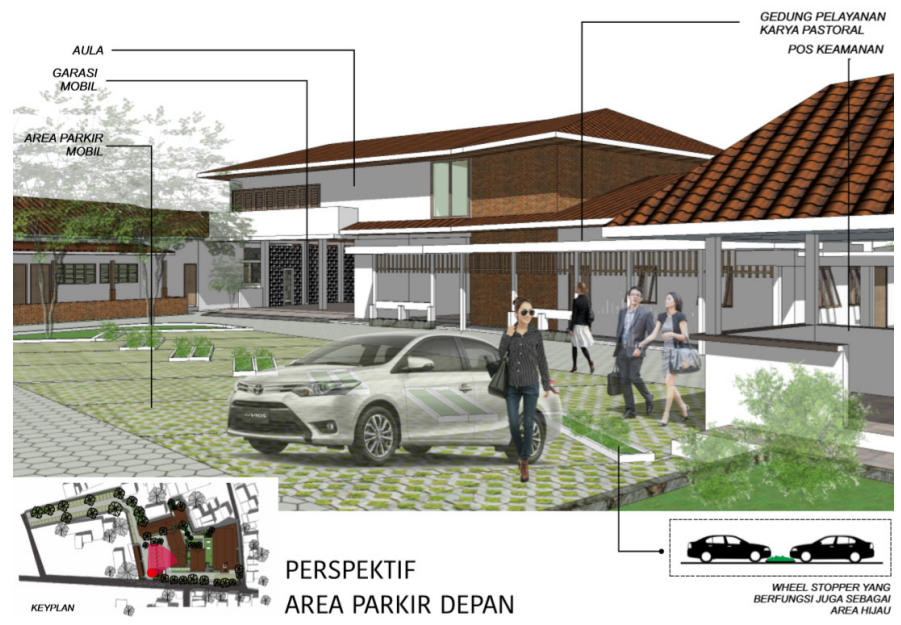

Gambar 17. Penggunaan Grassblock dan Desain Wheel Stopper Khusus yang Diharapkan dapat Menambah Jumlah Persentase Area Terbuka Hijau 


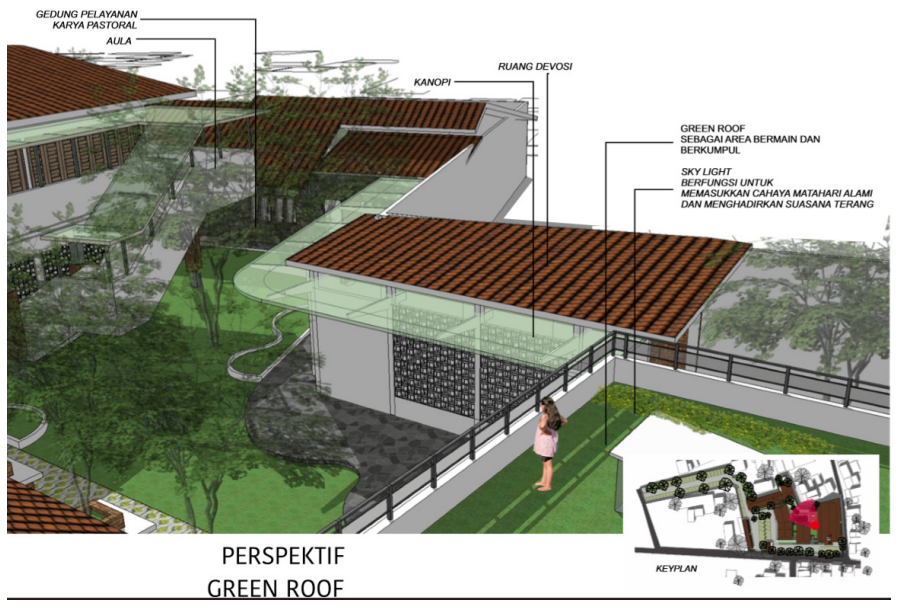

Gambar 18. Green Roof sebagai Salah Satu Alternatif Menambah Persentase Area Hijau

\section{Tata Ruang}

Peletakan tata ruang gereja yang kurang baik menyebabkan muncul ruang mati yang tidak berfungsi. Ada beberapa lorong sempit antara dua dinding massa berbeda yang tidak dapat difungsikan sebagai ruang dan tidak dapat diakses atau tidak dapat difungsikan sehingga sebenarnya lahan yang dapat dimanfaatkan secara keseluruhan menjadi tidak maksimal. Penataaan interior bangunaan gereja nantinya akan memiliki tantangan tersendiri karena mempunyai karakter yang berbeda dengan interior bangunan lainnya karena banyaknya simbol dan makna yang tidak bisa diabaikan begitu saja (Frederick Irianto \& Sari, 2014). Problema menonjol dari tata ruang di Gereja Santo Yoseph Medari adalah terbentuknya ruang-ruang terbuka serta sirkulasi (manusia dan kendaraan) yang saling mengganggu. Bidang-bidang bukaan, baik pada bangunan (Purnama et al., 2014) maupun tata ruang luar (Ryan Candra \& Poerbantanoe, 2018), akan memberikan tantangan pada sisi akustika bangunan. Oleh sebab itu penataan ruang terkait dengan konsep organisasi ruang perlu dilakukan secara komprehensif dengan meminimalisir kendala-kendala dan efek negatif yang dapat terjadi.

Ruang ditata ulang berdasarkan organisasi, kebutuhan dan zona sesuai sifat sehingga lahan dapat dimanfaatkan dengan optimal dan tidak terdapat ruang mati. Sebuaah fungsi kegiatan akan lebih bermakna ketika ditempatkan pada sebuah ruang yang tepat. Beberapa fungsi akan tetap seperti kondisi mula-mula dan memang tidak bisa diubah, seperti gedung utama gereja, namun bentuk dan aspek arsitekturnya bisa menyesuaikan dengan budaya lokal (Yusuf, 2016). Penataan ruang dan sirkulasi disinergikan agar mampu mengurangi atau bahkan menghilangkan ruang-ruang mati (dead spaces) dan menciptakan ruang-ruang fungsional sesuai kebutuhan, serta terciptanya sistem dan pola sirkulasi yang efektif. Selain itu perlu juga memperhatikan dan menerapkan sistem tata udara (penghawaan) dan tata cahaya yang baik,
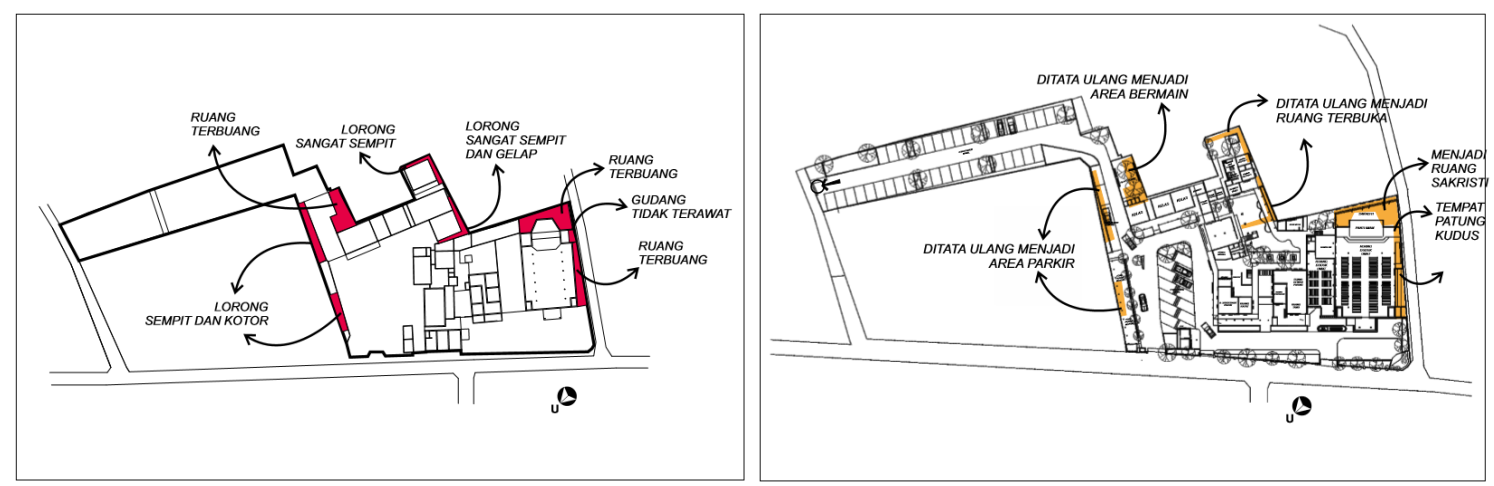

Gambar 19. Efisiensi Tata Ruang Eksternal dan Internal. Eksisting (Kiri) dan Usulan (Kanan) 
dalam upaya mendukung konsep bangunan eko desain yang selaras dengan lingkungan (Beatrix \& Fellicia, 2018), sesuai dengan orientasi masyarakat tradisional (Waisnawa \& Pramana, 2019) dan mencerminkan arsitektur nusantara (Manurung, 2014).

\section{Penambahan dan Relokasi Ruang}

Gereja Santo Yoseph Medari memiliki aktivitas beragam yang sangat aktif yang sebagian besar dilakukan secara kelompok. Gereja mengalami kekurangan ruang secara jumlah dan kualitas. Kegiatan dilakukan kadang dalam keadaan yang seadanya, di dalam ruangruang yang kurang memenuhi syarat. Banyak kegiatan kelompok yang belum terfasilitasi dengan baik oleh karena keterbatasan jenis dan jumlah ruang.

Penambahan ruang dilakukan sesuai kebutuhan dan prioritas. Terjadi penambahan ruang-ruang dalam hal jenis ruang dan kualitas ruang dengan desain ruang yang direncanakan dengan baik. Penambahan ruang juga dilakukan secara vertikal pada ruang tertentu berdasarkan masukan dan kebutuhan yang direncanakan. Terjadi relokasi ruang-ruang dikaitkan dengan sinergi hubungan ruang secara keseluruhan sebagai sistem kegiatan yang kondusif.

Kebutuhan jenis ruang pada komunitas gereja yang sangat aktif ini memerlukan upaya penataan berdasarkan prioritas. Keterbatasan lahan juga menjadi kendala yang harus diselesaikan, dengan alternatif membangun ruang secara vertikal. Ketersediaan dan keterbatasan lahan menjadi kendala untuk pembangunan/pengembangan gereja, baik dalam lingkup gedung/bangunan maupun penataan secara kawasan. Hal ini semakin dirasakan pada gereja-gereja yang terletak di area urban/kota (Priscilliana, Rahayu, \& Suhendar, 2019). Penambahan ruang perlu dilakukan sesuai kebutuhan dan prioritas agar keberadaan ruang-ruang baru dan lama selalu mendukung sistem kegiatan yang difasilitasinya. Jenis-jenis ruang tertentu telah ditambahkan, sebagian direlokasi karena kebutuhan sistem kegiatan yang aksesibel.

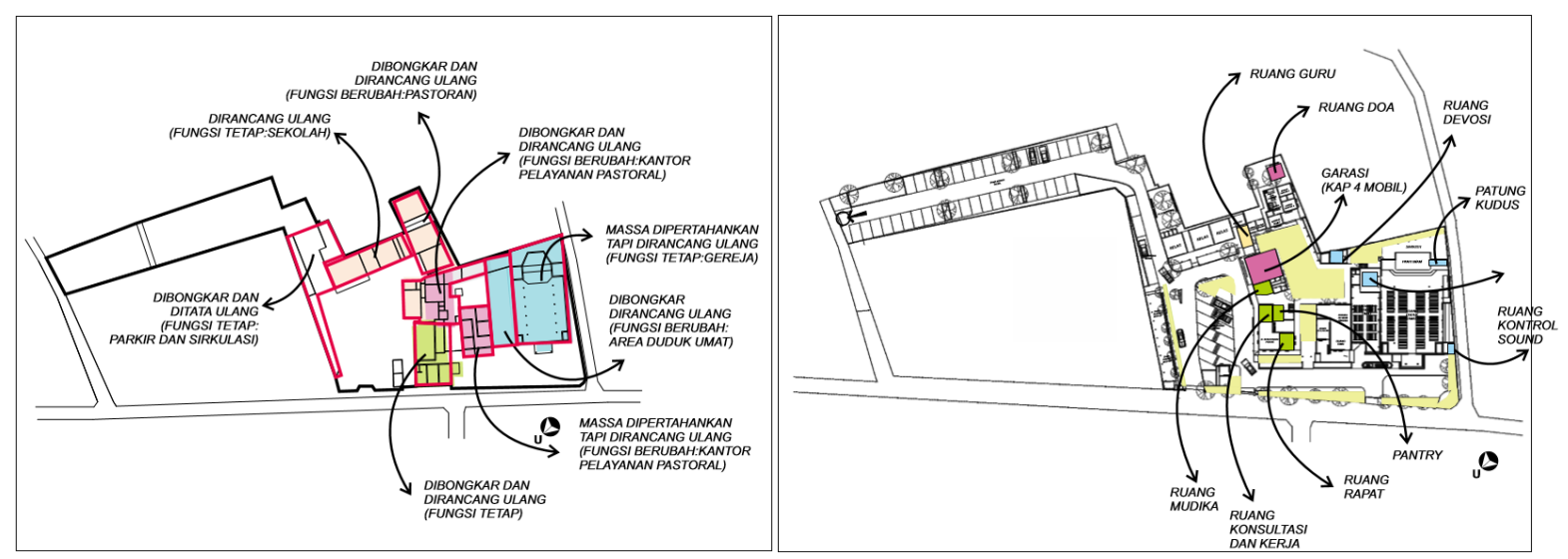

Gambar 20. Penataan Fungsi Ruang pada Bangunan. Eksisting (Kiri) dan Usulan (Kanan)
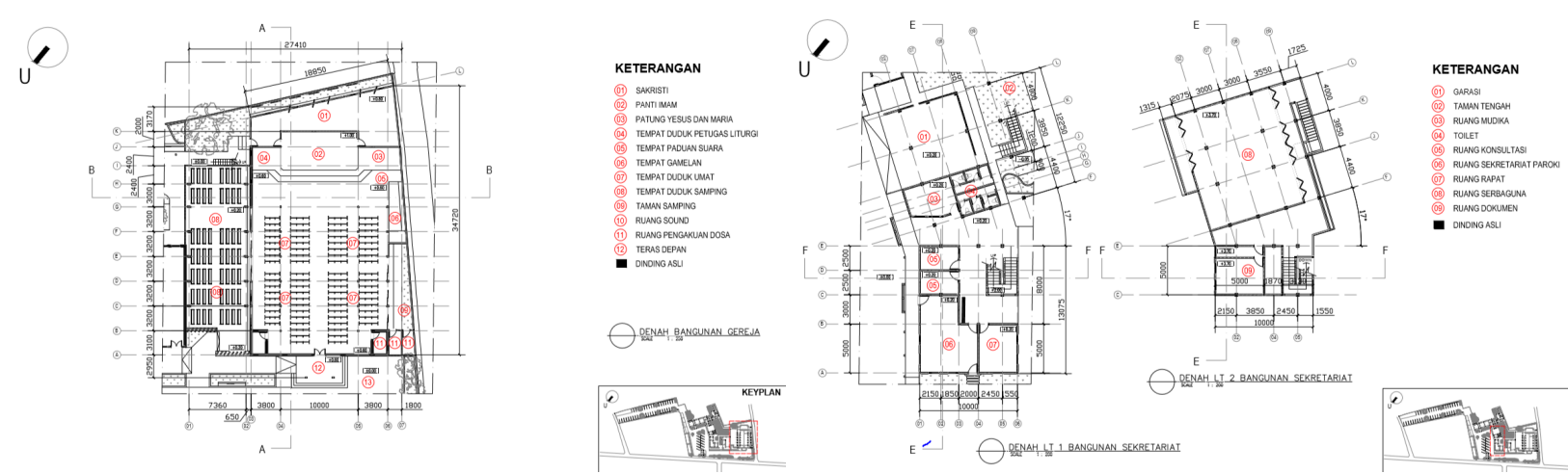

Gambar 21. Penataan Ruang yang Efisien Menyesuaikan Kebutuhan dan Fungsi 


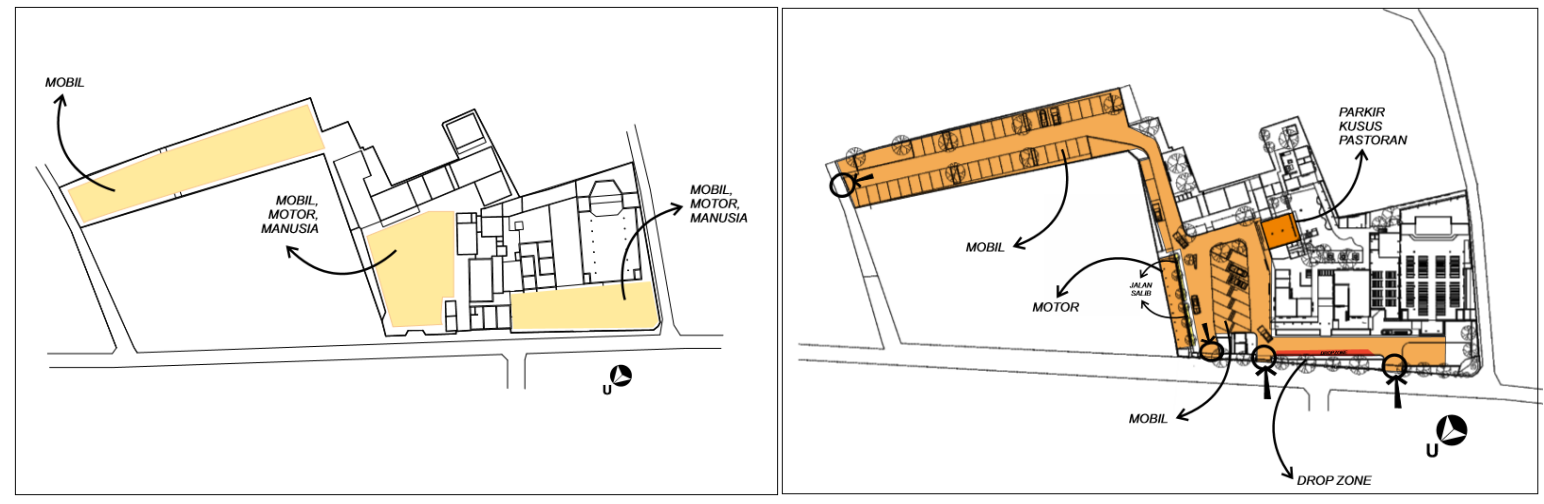

Gambar 22. Penataan Area Parkir Kendaraan. Eksisting (Kiri) dan Usulan (Kanan)

\section{Penataan Parkir}

Pada eksisting area parkir dibagi menjadi tiga bagian, yaitu area parkir halaman depan, area parkir tengah (utama) dan area parkir belakang. Area parkir depan hanya digunakan saat hari biasa atau saat tidak berlangsung perayaan ekaristi mingguan namun secara fungsi kurang optimal karena tidak jarang umat lebih memilih parkir di area parkir tengah yang lebih luas.

Area parkir dibagi menjadi dua bagian, yaitu area parkir depan dan area parkir belakang. Jika kapasitas parkir kendaraan di area parkir depan tidak mencukupi maka kendaraan langsung diarahkan menuju area parkir belakang. Bagian depan diutamakan sebagai area drop zone dan sirkulasi.

Problema parkir adalah terkait dengan problema sirkulasi manusia dan kendaraan. Pemisahan sirkulasi manusia dari sirkulasi kendaraan mutlak harus dilakukan dengan prinsip saling mendukung. Kebutuhan ruang parkir kendaraan dipenuhi sesuai perhitungan dalam jangka waktu tertentu, letaknya disesuaikan dengan sistem sirkulasi keseluruhan. Parkir juga terkait dengan sistem sirkulasi manusia di seluruh lahan, termasuk memenuhi kebutuhan para difabel.

\section{SIMPULAN}

Konsep kegiatan pengabdian pada masyarakat yaitu mampu memberikan dukungan dan pengaplikasian ilmu dan teknologi yang dapat dimanfaatkan masyarakat atau mampu membantu masyarakat dalam menyelesaikan permasalahan yang ada. Dari kegiatan pengabdian pendampingan perencanaan masterplan Gereja Santo Yoseph Paroki Medari, Sleman, Yogyakarta, ada beberapa hal yang dapat dijadikan catatan untuk dijadikan sebagai simpulan. Keterlibatan umat mulai dari tahap identifikasi masalah dan pemberian usulan memberi keyakinan bahwa hasil desain masterplan sudah bisa memenuhi sebagian besar harapan umat. Perlu adanya skala prioritas dalam menentukan desain masterplan mengingat keterbatasan lahan yang ada. Dalam proses desain masterplan ini telah memperhatikan dan menerapkan konsep arsitektur modern, namun tetap mengakomodasi arsitektur nusantara yang ramah lingkungan agar tercipta harmonisasi dan akulturasi dengan budaya setempat. Adanya masterplan bisa dijadikan sebagai acuan pengembangan dan pembangunan kawasan Gereja Medari di masa mendatang.

\section{PERSANTUNAN}

Ucapan terima kasih terutama ditujukan kepada Lembaga Penelitian dan Pengabdian pada Masyarakat Universitas Atma Jaya Yogyakarta atas dukungan perizinan/penugasan serta pendanaan untuk operasional kegiatan pengabdian ini. 


\section{REFERENSI}

Beatrix, Y., \& Fellicia, O. (2018). Penerapan Prinsip Eko Desain pada Rumah Tinggal dalam Kegiatan Service Learning. Seminar Nasional PPM UNESA, 1325-1335. Surabaya: LPPM - UNESA.

Chrisylla, M. (2016). Simbolisasi pada Rancangan Arsitektur Gereja Katolik Santo Petrus dan Gereja Katolik Santa Perawan Maria Tujuh Kedukaan di Kota Bandung Title: Architectural Design Symbolism Catholic Church of Saint Peter and The Virgin Mary Catholic Church Santa Grief Se. ARTEKS : Jurnal Teknik Arsitektur, I(1), 1-14.

Frederick Irianto, T., \& Sari, S. M. (2014). Re-Desain Gereja Katolik Santo Paulus di Surabaya Berdasarkan Ajaran Allah Tritunggal. Intra, 2(2), 337-341.

Hadinata, S., \& Yusran, Y. A. (2019). Evaluasi Keaslian Gereja Protestan di Indonesia Bagian Barat ( GPIB ) Immanuel (Gereja Merah) Kota Kediri berdasarkan Nara Grid. ARTEKS : Jurnal Teknik Arsitektur, 4(1), 1-12.

Indrastanti, S. R., Bawono, A. D. B., Nursiam, N., Sari, S. P., \& Mukharomah, W. (2017). Pendampingan Penyusunan Dokumen Rencana Pembangunan Jangka Menengah Desa. Warta LPM, 19(3), 120127. https://doi.org/10.23917/warta.v19i3.3228

M Nur and Priyoga, A. S. I. A. (2015a). Perancangan Kawasan Gedung Kampus Universitas Pandanaran (dengan pendekatan desain arsitektur modern). Journal of Architecture, 1(1), 1-20.

M Nur and Priyoga, A. S. I. A. (2015b). Semarang Airport dengan Pendekatan Desain Arsitektur Modern. Journal of Architecture, 1(1), 49-58.

Manurung, P. (2014). Arsitektur Berkelanjutan, Belajar dari Kearifan Arsitektur Nusantara. Simposium Nasional RAPI XIII - 2014 FT UMS, A75-A81. Retrieved from https://publikasiilmiah.ums.ac.id/ bitstream/handle/11617/5398/9.Parmonangan Manurung.pdf?sequence=1

Mayang Sari, S. (2007). Wujud Budaya Jawa sebagai Unsur Inkulturasi Interior Gereja Katolik. DIMENSI INTERIOR, 5(1), 44-53.

Medari, P. H. 80 T. P. S. Y. (2010). Buku Kenangan Dasawindu Gereja Katolik Santo Yoseph Medari, Yogyakarta (P. H. 80 T. P. S. Y. Medari, ed.). Yogyakarta: Panitia Harpa 80 Tahun Paroki Santo Yoseph Medari.

Medari, P. I. P. (2005). 75 th Gereja Katolik Santo Yusup Medari, Sleman (P. I. P. Medari, ed.). Sleman: Medari, Panitia Intan Paroki.

Priscilliana, S., Rahayu, R. L., \& Suhendar, E. (2019). Perancangan Gereja Kharismatik di Ruang UrbanDepok Lama. Prosiding SEMINAR NASIONAL'Komunitas Dan Kota Keberlanjutan', 417-425. Jakarta: Prodi Arsitektur - Universitas Indraprasta PGRI.

Purnama, M., Herwindo, R. P., Dwisusanto, B., Hartanto, S., Putri, K. A., Adryan, S., \& Setiawan, L. (2014). Perancangan Gereja St. Gabriel bandung. Bandung: LPPM - Universitas Katolik Parahyangan.

Rm. Antonius Dadang Hermawan. (2018). Profil Singkat Paroki St Yosep, Medari Yogyakarta (M. Paroki St Yosep, ed.). Yogyakarta: Paroki St Yosep, Medari Yogyakarta.

Ryan Candra, G., \& Poerbantanoe, B. (2018). Gereja Katolik di Malang. eDimensi Arsitektur Petra, 5(2), 89-96.

Sastrawan, I. W. W. (2019). Perencanaan Masterplan Pasar Batan Kendal Kelurahan Sesetan, Denpasar. Community Service Journal (CSJ), 1(2), 105-113.

Sastrawan, I. W. W., Darmawan, I. G. S., \& Widanan, I. W. (2018). Perencanaan Masterplan Pura Petasikan Desa Adat Sesetan. Community Service Journal, 1(1), 24-31.

Srirejeki, K., Faturahman, A., Warsidi, W., Ulfah, P., \& Herwiyanti, E. (2020). Pemetaan Potensi Desa 
Wibowo dan Purbadi - Pendampingan Perencanaan Masterplan Gereja ...

untuk Penguatan Badan Usaha Milik Desa dengan Pendekatan Asset Based Community-Driven Development. Warta LPM, 23(1), 24-34. https://doi.org/10.23917/warta.v23i1.8974

Sukawi, S. (2008). Ekologi Arsitektur : Menuju Perancangan Arsitektur HematEnergi Dan Berkelanjutan. Simposium Nasional RAPI VII. Surakarta.

Sumoprayogo, M. M., \& Arifin, L. S. (2018). Gereja Katolik Santo Yusup di Surabaya. eDimensi Arsitektur Petra, 6(1), 393-400.

Waisnawa, I. M. J., \& Pramana, I. M. B. (2019). Pengaruh Pola Ruang Terbuka Hijau Terhadap Sirkulasi Udara pada Rumah Tinggal. Segara Widya - Jurnal Hasil Penelitian dan Pengabdian Masyarakat, 7(1), 17-30.

Wibowo, A. P. (2014). Kriteria Rumah Ramah Lingkungan (Eco-Friendly House). Jurnal Muara: Sains, Teknologi, Kedokteran Dan Ilmu Kesehatan, 1(1), 1-10.

Yusuf, S. A. (2016). Wujud Akulturasi Arsitektur pada Aspek Fungsi, Bentuk, dan Makna Bangunan Gereja Kristen Pniel Blimbingsari di Bali. ARTEKS, Jurnal Teknik Arsitektur, 1(1), 15-30. https:// doi.org/10.30822/artk.v1i1.80 